\title{
Prediction of caesarean section for arrest of descent during the second stage of labour
}

\author{
Sunil Kumar Samal*, Setu Rathod
}

\begin{abstract}
Department of Obstetrics and Gynecology, Mahatma Gandhi Medical College \& Research Institute, Pillaiyarkuppam, Pondicherry, India
\end{abstract}

Received: 23 December 2016

Accepted: 31 January 2017

\section{*Correspondence:}

Dr. Sunil Kumar Samal,

E-mail: drsksamal1981@gmail.com

Copyright: $\odot$ the author(s), publisher and licensee Medip Academy. This is an open-access article distributed under the terms of the Creative Commons Attribution Non-Commercial License, which permits unrestricted non-commercial use, distribution, and reproduction in any medium, provided the original work is properly cited.

\begin{abstract}
Background: Friedman described the normal progress of labor in different curves for nulliparous and multiparous women in 1954. Any deviation from these curves during the second stage of labor is considered as failure to progress in the second stage of labor. The aim of the study is to define obstetrical risk factors for arrest of descent during the second stage of labour.

Methods: All singleton, vertex, term deliveries with an unscarred uterus, between December 2013 to November 2016 (3 years) were included. Univariable and multivariable analysis were performed to investigate independent risk factors associated with arrest of descent during the second stage of labor.

Results: The study included 7260 deliveries, of these 163 (3.3\%) were complicated with arrest of descent during the second stage of labor. Using a multivariable analysis, the following obstetric risk factors were found to be significantly associated with arrest of descent: primigravida $(\mathrm{RR}=7.8,95 \% \mathrm{CI}=6.9-8.7, \mathrm{p}<0.001)$, obesity $(\mathrm{RR}=1.8$, $95 \% \mathrm{CI}=1.6-2.0, \mathrm{p}<0.001)$, short stature $(\mathrm{RR}=2.3,95 \% \mathrm{CI}=1.9-2.8, \mathrm{p}<0.001)$, hypertensive disorders $(\mathrm{RR}=1.5,95 \%$ $\mathrm{CI}=1.3-1.8, \mathrm{p}<0.001)$, gestational diabetes $(\mathrm{RR}=1.5,95 \% \quad \mathrm{CI}=1.2-1.8, \mathrm{p}<0.001)$, free floating head before labour $(R R=3.4,95 \% C I=2.5-4.1, p<0.001)$, Occipito-posterior position( $R R=3.3,95 \% \mathrm{CI}=2.1-4.5, \mathrm{p}<0.002)$, Prelabour rupture of membrane $(\mathrm{PROM})(\mathrm{RR}=1.3,95 \% \mathrm{CI}=1.0-1.6, \mathrm{p}<0.02)$, induction of labour $(\mathrm{RR}=2.2,95 \% \mathrm{CI}=1.0-3.4$, $\mathrm{p}<0.03)$ and birth weight $>3.5 \mathrm{~kg}(\mathrm{RR}=2.2,95 \% \mathrm{CI}=2.0-2.4, \mathrm{p}<0.001)$. Deliveries complicated by arrest of descent resulted in cesarean section in $67 \%$ and $34 \%$ vaginal delivery.

Conclusions: In this era of increased public awareness and medicolegal events it is very crucial to assess and evaluate every woman in labor and to identify in advance the possibility of arrest in advanced labor so that a timely obstetric intervention possibly Cesarean section can prevent unnecessary maternal- fetal complications.
\end{abstract}

Keywords: Arrest of descent, Caesarean section, Risk factors, Second stage labour

\section{INTRODUCTION}

Friedman described the normal progress of labor in different curves for nulliparous and multiparous women in 1954. ${ }^{1}$ Any deviation from these curves during the second stage of labor is considered as failure to progress in the second stage of labor. Conventionally the causes for second stage arrest were categorized as the ' 3 Ps': passages; power; and passenger. ${ }^{2}$ To reduce surgical intervention in these cases, active management of labor was first introduced in $1969 .{ }^{3}$ Since then there has been no significant change in the management of arrest of descent in the second stage of labor. In literature, there are different studies describing diagnosis of arrest of descent and the importance of early recognition and intervention in these cases, different treatment possibilities like medical, instrumental and surgical. ${ }^{4-7}$ 
This study was designed to evaluate the epidemiology of arrest of descent in the second stage, in order to facilitate the identification of patients at risk. The objective of this study to critically analyze the demographic profile, associated risk factors, labor characteristics, identifiable causes in women who had undergone cesarean section for arrest of descent in second stage of labor.

\section{METHODS}

This was a retrospective observational study done between December 2013 to November 2016 (3 years) in Mahatma Gandhi Medical College \& Research Institute, Pondicherry. The data was collected from the records available in labour ward and Medical Record section. Inclusion criteria are all singleton pregnancy, vertex presentation, term gestation with unscarred uterus were included in the study. The length of the second stage of labor was limited to $2 \mathrm{~h}$ in nulliparous women (or $3 \mathrm{~h}$ if epidural analgesia was applied), and $1 \mathrm{~h}$ in multiparous women (or $2 \mathrm{~h}$ if epidural analgesia was applied). There were 7268 deliveries during this period and 163 (3.3\%) had arrest of descent during the $2^{\text {nd }}$ stage of labor. Among these 107 delivered by Caesarean section (67\%) and 56 (34\%) delivered Vaginally. The parameters studied were demographic profile, antepartum factors, intrapartum factors, any identifiable cause of arrest and risk factors for second stage arrest. The data was analysed critically and compared by using SPSS version 17 software. Statistical significance was considered when $p$ value $<0.05$.

\section{RESULTS}

Table 1 revealed that there was no significant difference between gestational age between both the groups. Primigravida, short stature and obesity were the common risk factors for arrest of descent during second stage of labour ( $\mathrm{p}$ value $<0.001$ )

Table 2 showed the antepartum factors like pregnancy induced hypertension (PIH), gestational diabetes mellitus (GDM), hypothyroidism, oocipito posterior position, prelabour rupture of membrane (PROM), free floating head before onset of labour and induced labour were more associated with second stage arrest.

Table 1: Demographic profile.

\begin{tabular}{|c|c|c|c|}
\hline Variable & $\begin{array}{l}\text { Study } \\
\text { Group } \\
{[n=107]}\end{array}$ & $\begin{array}{l}\text { Control } \\
{[n=56]}\end{array}$ & 'p' value \\
\hline Primigravida & $77 \%$ & $34 \%$ & 0.001 \\
\hline Multigravida & $23 \%$ & $66 \%$ & \\
\hline $\begin{array}{l}\text { Period of gestation } \\
\text { (mean) }\end{array}$ & 38.20 & 38.5 & 0.22 \\
\hline Obesity & $36 \%$ & $12 \%$ & 0.001 \\
\hline Short stature & $26 \%$ & $8 \%$ & $<0.001$ \\
\hline
\end{tabular}

Table 2: Antepartum factors.

\begin{tabular}{|l|l|l|l|}
\hline Variable & $\begin{array}{l}\text { Study group } \\
(\mathbf{n = 1 0 7})\end{array}$ & $\begin{array}{l}\text { Control } \\
(\mathbf{n = 5 6})\end{array}$ & $\begin{array}{l}\text { 'p' } \\
\text { value }\end{array}$ \\
\hline PIH & $17 \%$ & - & $<0.001$ \\
\hline GDM & $8 \%$ & - & $<0.001$ \\
\hline Hypothyroidism & $5 \%$ & - & $<0.001$ \\
\hline $\begin{array}{l}\text { Labour } \\
\text { Spontaneous }\end{array}$ & $62 \%$ & $96 \%$ & 0.002 \\
\hline $\begin{array}{l}\text { Labour Induced } \\
\text { Head free }\end{array}$ & $38 \%$ & $4 \%$ & 0.001 \\
\hline \begin{tabular}{l} 
(5/5 $5^{\text {th }}$ brim $)$ \\
\hline $\begin{array}{l}\text { Occipito post } \\
\text { position }\end{array}$
\end{tabular} & $56 \%$ & $10 \%$ & $<0.001$ \\
\hline PROM & $63 \%$ & $6 \%$ & $<0.001$ \\
\hline
\end{tabular}

Table 3 revealed intrapartum factors like unfavourable BISHOP score, cervix not well applied to presenting part, labour augmentation, birth weight $>3.5 \mathrm{~kg}$ and contracted pelvis were significantly associated with second stage arrest.

Table 3: Intrapartum factors.

\begin{tabular}{|c|c|c|c|}
\hline Variable & $\begin{array}{l}\text { Study } \\
\text { group } \\
{[n=107]}\end{array}$ & $\begin{array}{l}\text { Control } \\
{[n=56]}\end{array}$ & $\begin{array}{l}\text { 'p' } \\
\text { value }\end{array}$ \\
\hline \multicolumn{4}{|c|}{ Bishop's on admission } \\
\hline $\begin{array}{l}\text { Unfavourable } \\
\text { Favourable }\end{array}$ & $\begin{array}{l}75 \% \\
25 \%\end{array}$ & $\begin{array}{l}23 \% \\
77 \%\end{array}$ & 0.005 \\
\hline $\begin{array}{l}\text { Cervix not well } \\
\text { applied to } \\
\text { presenting part }\end{array}$ & $85 \%$ & $32 \%$ & $<0.001$ \\
\hline $\begin{array}{l}\text { Labour } \\
\text { augmentation }\end{array}$ & $92 \%$ & $45 \%$ & $<0.01$ \\
\hline $\begin{array}{l}\text { Foetal birth weight } \\
\text { (mean in } \mathrm{kg} \text { ) }\end{array}$ & 3.65 & 2.73 & 0.001 \\
\hline \multicolumn{4}{|l|}{ Type of pelvis } \\
\hline $\begin{array}{l}\text { Adequate } \\
\text { Contracted } \\
\text { [Mid pelvis] } \\
\text { [Outlet] }\end{array}$ & $\begin{array}{l}62 \% \\
38 \% \\
{[25 \%]} \\
{[75 \%]}\end{array}$ & $100 \%$ & \\
\hline \multicolumn{4}{|l|}{ Type of arrest } \\
\hline $\begin{array}{l}\text { Deep transverse } \\
\text { arrest } \\
\text { Direct occipito } \\
\text { posterior } \\
\text { Occipito anterior }\end{array}$ & $\begin{array}{l}94 \% \\
6 \% \\
-\end{array}$ & $100 \%$ & \\
\hline
\end{tabular}

In Table 4 by applying multivariate analysis relative risk, 95\% confidence interval and $\mathrm{p}$ value for each risk factors were calculated and it was found that risk factors like primigravida, short stature, obesity, hypertensive disorders, gestational diabetes mellitus, induction of labour, PROM, oocipito posterior position, free floating head before labour and birth weight $>3.5 \mathrm{~kg}$ were significantly associated with second stage arrest. 
Table 4: Risk factors for arrest of descent during second stage of labor multivariate analysis.

\begin{tabular}{|l|l|l|l|}
\hline Factors & RR & $\begin{array}{l}95 \% \\
\text { CI }\end{array}$ & $\begin{array}{l}\text { 'P' } \\
\text { value }\end{array}$ \\
\hline Primigravida & 7.8 & $6.9-8.7$ & $<0.001$ \\
\hline Short stature & 2.3 & $1.9-2.8$ & $<0.001$ \\
\hline Obesity & 1.8 & $1.6-2.0$ & $<0.001$ \\
\hline PIH & 1.5 & $1.3-1.8$ & $<0.001$ \\
\hline GDM & 1.5 & $1.2-1.8$ & $<0.001$ \\
\hline PROM & 1.3 & $1.0-1.6$ & $<0.02$ \\
\hline Induced labour & 2.2 & $1.0-3.4$ & $<0.03$ \\
\hline Occipito posterior position & 3.3 & $2.1-4.5$ & $<0.002$ \\
\hline $\begin{array}{l}\text { Free floating head before } \\
\text { labour }\end{array}$ & 3.4 & $2.5-4.1$ & $<0.001$ \\
\hline Birth weight $>3.5 \mathrm{~kg}$ & 2.6 & $2.0-2.4$ & $<0.001$ \\
\hline
\end{tabular}

\section{DISCUSSION}

Second stage arrest is one of the major cause for rise in CS rates in the last three decades. ${ }^{8}$ This study was aimed to identify the population at risk, so that a prediction can be done for second stage arrest. Independent risk factors identified in the present study were Primigravida (Nulliparity), hypertensive disorders, gestational diabetes mellitus, hypothyroidism, birth weight $>3.5 \mathrm{~kg}$, premature rupture of membranes and induction of labor. This is supported by a previous study by Feinstein $\mathrm{U}$ et al. ${ }^{8}$

Over $77 \%$ of cases are primigravida and this is supported by a previous study by Harper et al. ${ }^{9}$ on 32 patients and 329 controls. Our findings of prediction of duration of labour and arrest of descent during second stage by birth weight also supported by Harper et al. and Handa and Laros. ${ }^{7,9}$ We found premature rupture of membranes (PROM) a major risk factor for arrest of descent and it was supported by Handa and Laros who have reported that the time interval from the rupture of the membranes is an important determinant of the chances for CS, mainly due to a rise in the rates of failure to progress in the active phase of the labor, even when controlling for maternal fever and induction of labor. ${ }^{7} \mathrm{We}$ also found both PROM and induction of labor (either by Foley catheter, oxytocin or prostaglandin) are independent risk factors. After analyzing the results prediction of second stage arrest can be done by risk factors like Primigravidae with free floating head, occipito posterior position, big baby, obesity, PIH, GDM and PROM.

\section{CONCLUSION}

Major risk factors for arrest of descent during the second stage of labor were primigravida, short stature, obesity, hypertensive disorders, gestational diabetes mellitus, induction of labour and free floating head before labour. These risk factors should be carefully evaluated during pregnancy in order to reduce the morbidity and mortality due to second stage arrest. In this era of increased public awareness and medicolegal events it is very crucial to assess and evaluate every woman in labor and to identify in advance the possibility of arrest in advanced labor so that a timely obstetric intervention possibly Cesarean section can prevent unnecessary maternal fetal complications.

Funding: No funding sources

Conflict of interest: None declared

Ethical approval: The study was approved by the Institutional Ethics Committee

\section{REFERENCES}

1. Friedman EA. The graphic analysis of labor. Am J Obstet Gynecol. 1954;68:1568- 75.

2. Byrne MB, Keane D, Boylan P, Stronge JM. Intrauterine pressure and the active management of labor. J Obstet Gynecol.1993;13:453-6.

3. Olah KSJ. Failure to progress in the management of labour. Br J Obstet Gynaecol.1994;101:1-3.

4. Cardozo LD, Gibb DMF, Studd JWW, Vasant RV, Cooper DJ. Predictive value of cervimetric labor patterns in primigravidae. $\mathrm{Br} \mathrm{J}$ Obstet Gynaecol.1982; 89:33-8.

5. Rouse DJ, Owen J, Hauth J. Active-phase labor arrest: oxytocin augmentation for at least $4 \mathrm{~h}$. Obstet Gynecol. 1999;93:323-8.

6. Neuhoff D, Burke MS, Porreco RP. Cesarian birth for failed progress in labor. Obstet Gynecol.1989; 73:915-20.

7. Handa VL, Laros RK. Active-phase arrest in labor: predictors of cesarean delivery in nulliparous population. Obstet Gynecol.1993; 81:758-63.

8. Feinstein U, Sheiner E, Levy A, Hallak M, Mazor M. Risk factors for arrest of descent during the second stage of labor. Int J Gynaecol Obstet. 2002;77(1):714.

9. Harper DM, Johnson CA, Harper WH, Liese BS. Prenatal predictors of cesarean section due to labor arrest. Arch Gynecol Obstet.1995;256:67-74.

Cite this article as: Samal SK, Rathod S. Prediction of caesarean section for arrest of descent during the second stage of labour. Int J Reprod Contracept Obstet Gynecol 2017;6:963-5. 